\title{
Construction, Validity, Reliability and Effectiveness of the Psycho-Educated Module Management of Forgiveness
}

\author{
Alyeca Eric ${ }^{1}$, Salmah Mohamad Yusoff ${ }^{*}$, Nur Akalili Khairah Ishak ${ }^{1}$ \\ ${ }^{1}$ Faculty of Cognitive Sciences and Human Development, Universiti Malaysia Sarawak \\ *Corresponding author, e-mail: mysalmah@unimas.my
}

\begin{abstract}
This study is aimed at developing and testing the Application of Forgiveness Management Module on University Malaysia Sarawak (UNIMAS) trainee counselors. The main focus of the study is focused on the module development process and the effect of the module on the emotional, cognitive and behavioral aspects of an individual. The study was conducted using a qualitative and quantitative combination method. The sample of the study consisted of 8 UNIMAS counseling students. The Instrument Level of Anger Scale (LAS) and Tendency Forgive Scale (TTFS) are used to identify the appropriate study sample to follow this module. The built-in Forgiveness Management module has a high authenticity value of $82.2 \%$. In addition, the reliability test of this module has a high coefficient of Cronbach's Alpha coefficient of 0.884 . This proves that participants have learned new knowledge better understanding the concept of forgiveness than before following the modules that have been conducted.
\end{abstract}

Keywords: Group Counseling, Modules, Forgiveness Therapy, Behavioral Emotive Rational Therapy (REBT)

How to Cite: Eric, A., Yusoff, S.M., \& Ishak, N.A.K., (2019). Construction, Validity, Reliability and Effectiveness of the Psycho-Educated Module Management of Forgiveness. International Journal of Research in Counseling and Education, 3(2), 95-102.

\section{Introduction}

The research was conducted on the development of forgiveness management modules and the application of the module which was developed into psychopendidikan group counseling sessions. The counseling approach of the psychopendidikan group that will be conducted by researchers is to help students restore their emotional self through the forgiving management module. Counseling of psychopendale groups involves the exchange of information between counselors and group members. The information provided by the counselor plays an important role in helping members of the group reach a sense of the issues faced and want to be resolved.

In addition, the research conducted by researchers also aims to develop modules with good validity, reliability and effectiveness. Module is a method of teaching used to convey information or knowledge to an individual. The competence of the individual is a measure of the achievement and effectiveness of the delivered mood (Sidek Mohd Noah and Jamaluadin Ahmad, 2005). The modules developed need to go through certain processes and phases before becoming a quality module. The researcher made the Sidek Module Development Model (Sidek Mohd Noah and Jamaludin Ahmad, 2005) as a guide to developing a forgiving management module.

The main issue of the research conducted by the researcher was apreciation. Kemaafan is one of the processes that helps an individual overcome negative feelings such as anger and hate against individuals who have caused them to experience bitter experiences in their lives (Enright and Fitzgibbons, 2002). Aphrodisiac therapy is one of the mediums used to help the client get rid of his anger and while at the same time learning to understand the situation he faced. According to Enright and Fitzgibbons (2002), this therapy involves four main phases, namely the phase of uncovering your anger, the phase of deciding to forgive, the phase of working on forgiveness, and the deep phase (deepening).

Advances in terms of information technology (ICT) have affected the society, especially young people in Malaysia. The information technology introduced, especially social media such as Facebook, Twitter, 
Instagram, Blog and so on has always been the main attraction of the community to get the latest information on the issues around them. However, there are also few individuals who make social media a medium for them to express their positive or negative feelings.

The students are also excluded from doing such things. For example, there is a page on Facebook known as "Unimas Confession" opened to give consumers the opportunity especially students to express and share the various issues they are experiencing. This has led the students to express their feelings and issues through social media rather than professional services such as counseling.

In the meantime, studies on the use of forgiveness therapy in the Malaysian context are limited. The study and use of forgiveness therapy is more widely practiced in western countries. This makes it difficult for researchers to find resources related to forgiveness therapy in the Malaysian context. This issue encourages researchers to be more active in conducting research on forgiving therapies in order for this therapy to be widely used in Malaysia.

The main objective of this study is to develop and identify the effects of psychopathy management modules on emotional, cognitive and behavioral aspects among counseling students at Universiti Malaysia Sarawak (UNIMAS).

\section{Literature Review}

The researcher used the module development model introduced by Sidek Mohd Noah and Jamaludin Ahmad (2005). This conceptual framework gives an overview of the processes involved in the construction and implementation of a module.

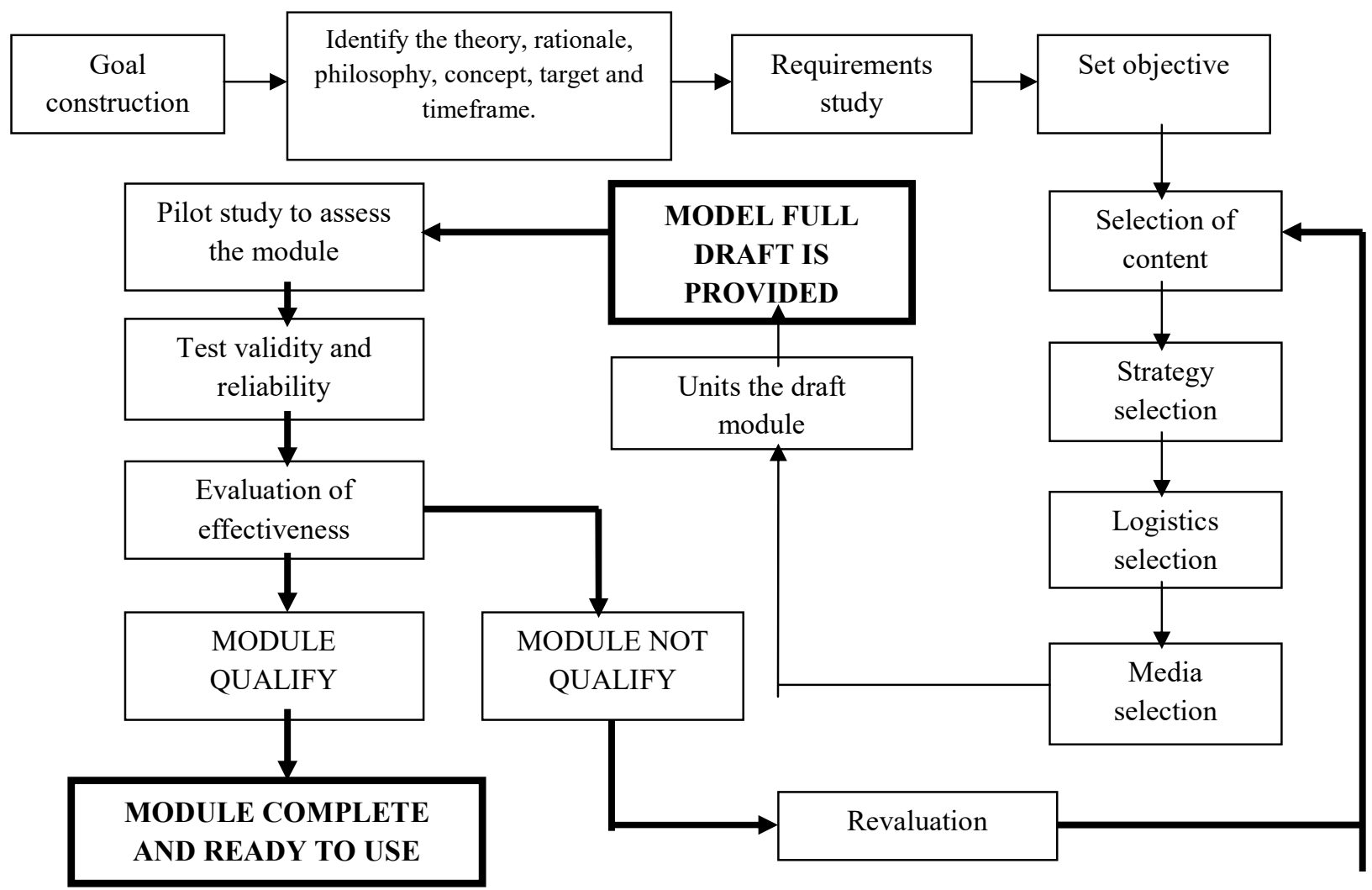

Figure 1: Sidek Modek development model (Sidek Mohd Noah \& Jamaludin Ahmad, 2005)

\section{Method}

The study was conducted using quantitative and qualitative combinations. Quantitative methods are a method of collecting data in numbers or numbers. The quantitative method in this study involved the measurement of data obtained from questionnaires distributed to the sample. Qualitative methods are data 
collection processes that do not involve numbers or numbers. The qualitative method in this study involved the data obtained from observation of the study sample during the group counseling session and interviews with the sample of the study after the program ended.

The data analysis in this study was conducted to measure the level of reliability, validity and effectiveness of the forgiving management module. The reliability level of the module was analyzed using the Alpha Cronbach coefficient value method through Statistical Packages for the Social Sciences (SPSS). The validity of the module was evaluated by three (3) module experts and subsequently, the effectiveness of the module depends on the results of the feedback provided by the sample of the study.

The population of the study consisted of students from the University Malaysia Sarawak Counseling Program (UNIMAS). The sample was selected based on the results of the screening process conducted through the distribution of questionnaires. Distribution of questionnaire forms is the first step taken before selecting a sample of the study. This process is important to ensure that the selected research sample is appropriate and feasible to be involved in this Forgiveness Management Module.

This study was conducted at the Faculty of Cognitive and Human Development Sciences Universiti Malaysia Sarawak (UNIMAS), Kota Samarahan. The researcher used questionnaires to analyze the needs of the study sample. The questionnaire was modified from two instruments namely Level of Anger Scale (LAS) and Tendency to Forgive Scale (TTFS). The Level of Anger instrument (LAS) built by Russell (2013) aims to measure the level of anger of an individual. This instrument contains 18 items rated using Likert scale; 1 (strongly disagree), 2 (disagree), 3 (neutral), 4 (agree) and 5 (strongly agree). If the score is high, it shows that the individual has a high level of anger. In this study, researchers have chosen only 12 items to be used. The Tendency to Forgive Scale (TTFS) instrument built by Russell (2013) aims to measure the level of tendency of individuals to forgive other individuals. This instrument contains 18 items rated using Likert scale; 1 (strongly disagree), 2 (disagree), 3 (neutral), 4 (agree) and 5 (strongly agree). If the score is high, it shows that the individual has a tendency to not pardon the high. In this study, researchers have chosen only 12 items to be used.

CONSTRUCTION OF MODULE PSYCHO-EDUCATION FORGIVENESS MANAGEMENT

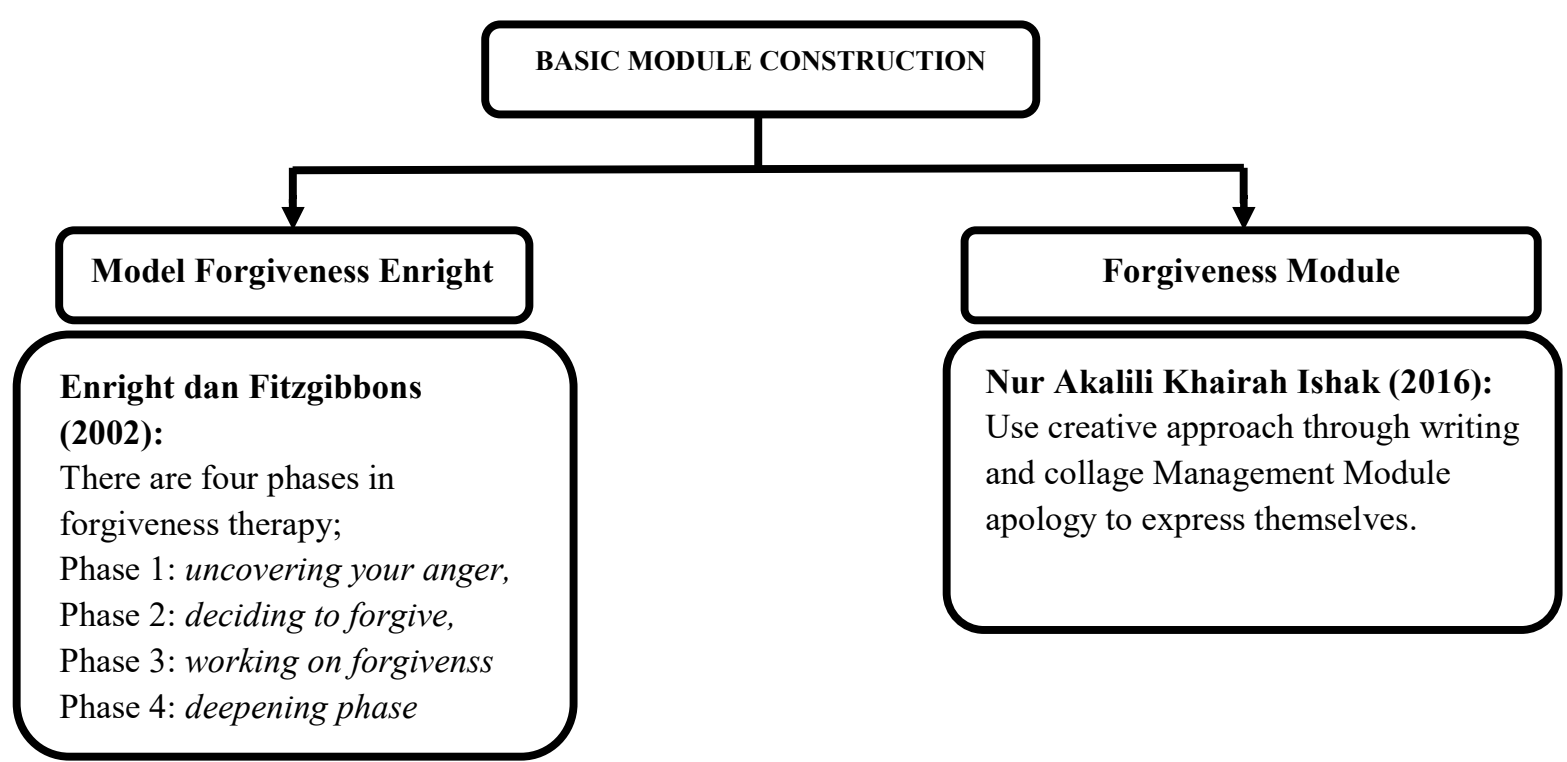

(Source: Enright \& Fitzgibbons, 2002; Nur Akalili Khairah Ishak, 2016)

Figure 2: Basic Development of the Psycho-Education Forgiveness Module Management

The psycho-educated modules of this forgiveness management are built on four phases of forgiveness in the Enright forgiveness model (Enright and Fitzgibbons, 2002) and the adaptation of a creative approach based on the creative approach developed by Nur Akalili Khairah Ishak (2016). 


\section{Results and Discussion}

\section{Test Validity of the Management Module of Forgiveness}

Three expert module experts comprising lecturers of the Cognitive and Human Development Faculty of UNIMAS were appointed to conduct evaluations on forgiving management modules. Evaluation by module validity experts was carried out using a questionnaire which contained assessments in terms of the validity of the module content in general and the validity of the module content according to the suitability of the session as well as the activities carried out.

The following is a computational formula used by the researcher to calculate the achievement of the validity of the module:

Expert Score Amount (34+44+38)/3 X 100\% = Achievement of Validity (77.4\%)

Maksimum Score (50)

Figure 3: Module Validity Values Calculation Formula

The Forgiveness Management Module developed by the researcher reached a validity value of $77.4 \%$. According to Sidek and Jamaludin (2005), a good module is a module that has an authenticity value of more than $70 \%$. Therefore, the validity of the module content obtained shows that the Management Module of the Kemaafan has a high validity value and is suitable for intervention purposes.

\section{Reliability Testing of the Management Modules of Kemaafan}

Reliability test of forgiveness management module was conducted through a questionnaire distributed by the researcher to each participant at the end of the program. The module reliability questionnaire used by researchers consists of 33 items constructed based on the objectives of each submodule. Each item is assessed by one (1) likert scale up to five (5).

Here are the points for each given likert scale:

\begin{tabular}{cc}
\hline Scale & Point \\
\hline Strongly disagree & 1 \\
Disagree & 2 \\
Not sure & 3 \\
Agree & 4 \\
Strongly agree & 5 \\
\hline
\end{tabular}

Table 1: Likert Scale

The data obtained were analyzed using Cronbach's Alpha coefficient.

\begin{tabular}{cc}
\hline Cronbach's Alpha & Number of questions (n) \\
\hline .884 & 32 \\
\hline
\end{tabular}

Table 2 shows the reliability statistics of the Management Module Management with the value of Cronbach's Alpha 0.884 . This indicates that this module has a high reliability value and the measurement scale for this study can be adopted. 


\section{Results of the Effectiveness of the Management of the Kemaafan Module}

The researcher distributed the questionnaires for two participants, namely pre-test and after (posttest) program. There are 30 questions of effectiveness built on content from the eight sub-modules that have been built. Analysis is carried out using the SPSS software to see the difference between the participants' understanding of the modules before and after the program. The researcher has developed the null hypothesis (Ho1) and uses the t-paired samples statistics procedure to see the difference.

Ho1: There is no significant difference between pre-test and post-test scores for participants attending pardon management programs.

Figure 4: Null hypothesis (Ho1)

\begin{tabular}{lccr}
\hline \multicolumn{1}{c}{ Test } & N & Mean & Standard Deviation \\
\hline Pre-Test & 16 & 30.9375 & 1.38894 \\
Post-Test & 16 & 30.1250 & .34157 \\
\hline
\end{tabular}

Table 3: Mean for pre and post test program forgiveness management

Table 3 shows statistical descriptive tests in the implementation of forgiveness management modules. The test results show that there are differences between pre-test and post-test scores for participants who follow the forgiveness management program. The pre-test mean is 30.9375 while the posttest value is 30.1250 .

\begin{tabular}{rccccc}
\hline Test & $\begin{array}{c}\text { Mean } \\
\text { difference }\end{array}$ & $\begin{array}{c}\text { Standard } \\
\text { Deviation }\end{array}$ & T-Calculate & $\begin{array}{c}\text { Degree of } \\
\text { Freedom (df) }\end{array}$ & $\begin{array}{c}\text { Significant } \\
\text { 2-tails }\end{array}$ \\
\hline $\begin{array}{l}\text { Pre-Test } \\
\text { Post-Test }\end{array}$ & .81250 & 1.37689 & 2.360 & 15 & .032 \\
\hline
\end{tabular}

Table 4: T-Repetitive Variable Test Results

Table 4 shows the mean for pre-test and post-test after attending a forgiving management module program. Based on the test of repeat t-test, the mean of the pre-test is $(\mathrm{M}=30.9375, \mathrm{SP}=1.38894)$ while the mean for the post-test is $(\mathrm{M}=30.1250, \mathrm{SP}=0.34157)$.

\section{Interviews}

The interview was conducted by the researcher after a week of the program ended. Each participant was interviewed individually to get feedback on some of the issues related to the forgiving management module that has been implemented. The following are interviews with seven participants;

\section{Experience participating in the Psycho Education Educator Management Module}

Based on interviews, all participants stated that they learned a whole lot of new things during the apology management module program. In addition, participants also stated that exchange of opinions and knowledge sharing during group counseling sessions helped them understand the concept of forgiveness.

Participant 1: ".. I can recognize new people when entering this group. Then I learned the meaning of forgiveness from various points of view. The views given helped me gain insight on what was forgiving ... "

Participant 6: "... I'm very excited to join this module as this is my first time listening to the forgiving management module. Through this module I learned to forgive ... "

\section{Knowledge of the concept of forgiveness}

Based on the interviews, each participant stated that they are more clear about the true concept of forgiveness especially about four phases of forgiveness. 
Participant 1: "... this module helps me find the true meaning of forgiveness. Once I understand what a true forgiveness is, I become aware that I still have a feeling of anger but now I feel that I am more open to forgiving..."

Participant 5: "... this module helps me understand what pardon means and makes me more open to forgiving others ..."

\section{Effect on participating in the Management of Forgiveness Module}

Based on interview results. All participants stated that this memorable management module had a positive impact on themselves from emotional, cognitive and behavioral aspects.

Participant 2: "... after joining this module, I feel better than ever. The two-day activities helped me to think deeper about the issues I was facing. This helps me change my negative perspective on my coursemate to a more positive one. Now I have started to reproach him ..."

Participant 5: "... this module has had a positive impact on me. I feel calmer and chesty. After following this module I became more rational before taking any action. My brain became less fiber and I became softer with others ... "

Based on interviews, all participants stated that this forgiveness management module had a positive impact on them. Most participants say that this module has influenced their emotions, cognites and behaviors that indirectly led to a positive change of openness to give forgiveness.

\section{Implications}

\section{Theoretical Aspect}

The modul management module used in this study was developed based on Sidek Modek's development model (Sidek Mohd Noah and Jamaludin Ahmad, 2005) and Enright forgiveness model (Enright and Fitzgibbons, 2002). In addition, researchers also adapted the modules developed by the previous researcher, the forgiving management module using the creative approach (Nur Akalili Khairah Ishak, 2016). These referenced models help the researcher develop a more structured and more systematic module.

\section{Practical Aspects}

The developed leadership modules have high efficacy and reliability values. The results of the effectiveness and reliability test show that the module developed is suitable and can be used as a reference to future researchers. Applying the forgiving management module in psychopendidikan group counseling sessions has helped participants become more aware of issues related to forgiveness and how these issues impact participants.

\section{Research Methods}

The researchers have used qualitative and quantitative mix methods to carry out this study. A quantitative analysis was done using several instruments such as Russell's (2013) anger and forgiveness questionnaire and a reliability, validity and validity questionnaire. The use of Russell (2013) anger and forgiveness questionnaire is used to identify the level of anger and forgiveness of an individual. This instrument helps the researcher identify the appropriate respondents to undergo a forgiving management module. In addition, the reliability and effectiveness questionnaire distributed to the study participants as well as the validity forms distributed to the module assessor helped the researcher produce a good module.

\section{Counselor and Counselor Coach}

Important elements such as the four phases of forgiveness in Enright's forgiveness model help counselors and trainee counselors better understand the application of forgiveness concepts in counseling sessions. Mosul managing director also helps counselor and trainee counselor understand the level of anger and forgiveness found in the client. It is important to enable train counselors and counselors to conduct exploratory and interventions that are appropriate to clients' emotional and cognitive needs.

\section{Participants}

Based on interviews, all participants stated that the aphorism management module had a positive impact on them. Participants stated that they were only aware of the level of anger and forgiveness found 
within them. Additionally, there are participants who claim that they just know that forgiveness has its own phases and it helps them to learn how to manage forgiveness.

\section{Conclusion}

The built-in Forgiveness Management module has reached a high level of validity, reliability and effectiveness and is suitable for intervention purposes. This module is applicable to various age groups and community layers. The development of this module will help individuals who want to learn knowledge about forgiveness management, which indirectly helps from the point of self development towards a more positive.

\section{Acknowledgement}

Thank you to Dr Salmah Mohamad Yusoff for being my supervisor of the Final Year Project, the module experts involved in the evaluation of the module, Universiti Malaysia Sarawak (UNIMAS), research participants and all parties involved directly or indirectly in the conduct of this study.

\section{References}

Amalia Madihie \& Salmah Mohamad Yusoff. (2016). Pembinaan kesahan dan kebolehpercayaan intervensi kaunseling modul kecemerlangan diri berdasarkan 6 nilai bersama yang memfokuskan kepada transformasi PNS. Dicapai daripada https://www.researchgate.net/publication/297313810

Amalia Madihie \& Sidek Mohd Noah. (2013). An application of the Sidek module development in REBT counselling intervention module design for orphans. Procedia84, pp. $\quad 1481-1491$.

Aslina Ahmad. (2013). Kesan intervensi psiko-pendidikan terhadap tingkah laku murid sekolah menengah oleh guru bimbangan dan kaunseling. (Tesis dan disertasi). Universiti Malaya.

Corey, G. (2009). Theory \& practice of counselling and psychotherapy ( $\mathcal{(}^{\text {th }}$ ed.). United States of America: Brooks/Cole.

Corey, G. (2012). Theory \& practice of group counseling ( (th $^{\text {th }}$ ed.). United States of America: Brooks/Cole, Cengage Learning.

Degges-White, S. \& Colon, B. R. (2014). Expressive art intervention for school counsellor. New York: Springer Publishing Company.

Enright, R. D., \& Fitzgibbons, R. (2002). Helping clients forgive: An empirical guide for resolving anger and restoring hope. Washington, DC: American Psychological Association.

Fassinger, R. \& Morrow, S., L. (2013). Toward best practices in quantitative, qualitative, and mixedmethod research: A social justice perspective. Journal for Social Action in Counseling and Psychology, $5(2), 69-83$.

Freedman, S. \& Enright, R., D. (2017). The use of forgiveness therapy with female survivors of abuse. Journal of Women's Health Care, 6 (3), 1-6.

Freedman, S. \& Zarifkar, T. (2016). The psychology of interpersonal forgiveness and guidelines for forgiveness therapy: What therapists need to know to help their clients forgive. Spirituality in Clinical Practice, $3(1), 45-58$.

Hall, J., H. \& Finchman, F., D. (2005). Self-forgiveness: The stepchild of forgiveness research. Journal of Social and Clinical Psychology, 25 (5), 621-637.

Ida Hartina, A. (2006). Memimpin kaunseling kelompok. PTS Professional.

Jenkins, T. (2012). Forgiveness as a healing agent in cases of traumatic violence. (Tesis dan disertasi). School of Criminology Simon Fraser University.

Macaskill, A. (2005). The treatment of forgiveness in counselling and therapy. Dicapai pada Oktober 6, 2017, daripada https://www.researchgate.net

Masson, R. L., Jacobs, E. L., Harvill, R. L., \& Schimmel, C. J. (2012). Group counselling interventions and techniques (7nd ed.). Brooks/Cole, Cengage Learning.

McLeod, J. (2003). Doing counselling research (2 ${ }^{\text {nd }}$ ed.). London: SAGE Publications. 
Nurul Iman bdul Jalil \& Mastura Mahfar. (2016). The validity and reliability of rational emotive behavioural therapy module development for university support staff. Asian Social Science, 12 (2), 129-137.

Orbon, M., Mercado, J. \& Balila, J. (2015). Effects of forgiveness therapy on recovery among residents of drug rehabilitation centers. Procedia-Social and Behavioral Sciences, 165, pp. 12-20.

Sidek Mohd Noah \& Jamaludin Ahmad. (2005). Pembinaan modul: Bagaimana membina modul latihan dan modul akademik. Serdang, Selangor: Penerbit Universiti Putra Malaysia.

Snider, J. J. (2015). Moral injury: Repair through self-forgiveness (Tesis dan disertasi). Dicapai daripada http://digitalcommons.georgefox.edu/psyd/182

Terzino, K. A. (2010). Self-forgiveness for interpersonal and intrapersonal transgressions $\quad$ (Tesis dan disertasi). Dicapai daripada http://lib.dr.iastate.edu/etd/11470

Turnage, B., F., Jacinto, G., . \& Kirven, J. (2003). Reality therapy, domestic violence survivors, and selfforgiveness. International Journal of Reality Therapy, 22 (2), 24-27. Dicapai daripada https://www.researchgate.net/publication/270571636 